\title{
Development, Social Citizenship and Human Rights: Re-thinking the Political Core of an Emancipatory Project in Africa
}

\author{
Michael Neocosmos*
}

\begin{abstract}
The paper begins from the axiomatic point that, despite the form it eventually took, namely that of a neo-colonial process, development was understood and fought for in Africa as [part of] an emancipatory political project central to the liberatory vision of the pan-African nationalism which emerged victorious at independence. Indeed independence was always seen, by radical nationalism in particular, as only the first step towards freedom and liberation from oppression, the second being economic development. Indeed 'economism' and 'statism' were mirror images of each other: it was believed that only the economy could liberate humanity and that only the state could drive the economy to progress. Today, the first proposition has been retained but the second has been dropped from hegemonic discourse. Yet the two are inseparable twins; it is in fact the case that just as the latter is false so is the former, for human emancipation is and can only be a political project. While development today is said to be guided by the (not so invisible) "hand of the market", the state has simultaneously 'subcontracted' many of its development management functions to external bodies such as NGOs. These are frequently simply new parastatals, vehicles for social entrepreneurship for a 'new' middle-class of development professionals. We have now a new form of state rule which forms the context for re-thinking development and politics. Central to this new form of rule is the hegemony of human rights discourse. This paper begins by reviewing the political assumptions of the nature of citizenship underlying T.H. Marshall's argument for 'social rights'; it provides a critique of human rights discourse and civil society from an emancipatory perspective, situating these within the new forms of imperialism and comments on the character of political parties and social movements in understanding political emancipation today. It argues that in Africa, if
\end{abstract}

* Director, Global Movements, Monash, South Africa.

Email: michael.neocosmos@up.ac.za 
one is to think an emancipatory project, citizenship must be conceived as active citizenship, and political subjectivity must be thought, not as management or opinions but, following the work of Badiou and Lazarus, as the freedom to think new 'possibles'.

\section{Résumé}

Cette étude part du point axiomatique selon lequel, en dépit de la forme finalement prise par le développement, à savoir celle d'un processus néocolonial, pour lequel l'Afrique a lutté et qui fait partie d'un projet politique émancipateur au cœur de la vision libératrice du nationalisme panafricain qui s'est révélé victorieux à l'indépendance. De fait, pour le nationalisme radical en particulier, l'indépendance a toujours été considérée comme la première étape vers la liberté et la libération de l'oppression, la seconde étant le développement économique. En effet, « l'économisme » et « l'étatisme » ont été l'image inversée de l'un et de l'autre ; l'on croyait que seul l'économie pouvait libérer l'humanité et que seul l'état pouvait conduire l'économie au progrès. Aujourd'hui, la première proposition a été retenue mais la seconde a été effacée du discours hégémonique. Cependant, les deux sont des jumelles inséparables ; le fait est que tout comme la première, la seconde proposition est fausse car l'émancipation humaine est et ne peut être qu'un projet politique. Alors qu'il est dit qu'aujourd'hui le développement est guidé par la « main du marché » (pas si invisible), l'état a simultanément « sous-traité » beaucoup de ses fonctions de gestion du développement à des organismes extérieurs tels que les ONG. Celles-ci ne sont souvent que de nouveaux organismes paraétatiques, des véhicules d'entreprenariat social aux mains d'une nouvelle classe moyenne de professionnels du développement. Nous avons maintenant une nouvelle forme d'étatisme qui constitue le cadre d'une nouvelle réflexion sur le développement et la politique. L'hégémonie du discours des droits humains est au cœur de ce nouvel étatisme. Cette étude commence par passer en revue les hypothèses politiques sur la nature de la citoyenneté qui sous-tendent l'argument de T.H. Marshall en faveur des «droits sociaux ». Cela suscite une critique du discours des droits humains et de la société civile à partir d'une perspective émancipatrice, en les situant dans les nouvelles formes de l'impérialisme et dans les commentaires portant sur la nature des partis politiques et des mouvements sociaux, dans la compréhension actuelle de l'émancipation politique. Selon l'argumentation qui en est faite ; $\mathrm{Si}$, en Afrique, l'on pense à un projet émancipateur, il importe que la citoyenneté soit conçue comme une citoyenneté active, et la subjectivité politique doit être pensée, non pas en termes de gestion ou d'avis, mais à la suite des travaux de Badiou et de Lazarus, en terme de liberté de penser à de nouvelles « possibilités ».

\section{Introduction}

I begin from the axiomatic point that, despite the form it eventually took, namely that of a neo-colonial process, development was understood and fought for in Africa as (part of) an emancipatory project central to the 
liberatory vision of the pan-African nationalism which emerged victorious at independence. Indeed independence was always seen, by radical nationalism in particular, as only the first step towards freedom and liberation from oppression, the second being economic development. It was after all Nkrumah who noted that 'true liberation' would only finally come with national economic independence from imperial domination. Up to this day Africa is seen by many nationalists as unfree because of its economic dependence, and not so much because of its politics, as if the road to freedom, justice and equality was not necessarily a political one.

The failure of development to emancipate the people of Africa was not the result of a betrayal or a con trick, it was rather the effect of a common worldwide conception in the twentieth century, a view according to which human emancipation could only be achieved through one form of state politics or the other. Indeed, economism and statism were mirror images of each other: it was believed that only the economy could liberate humanity and that only the state could drive the economy to progress. Today, the first proposition has been retained but the second has been dropped from hegemonic discourse. Yet the two are inseparable twins; it is in fact the case that just as the latter is false so is the former, for human emancipation is and can only be a political project. To maintain that human emancipation is essentially an economic question, is to necessarily collapse into statism and to foreclose the possibility of political agency. Today, the interests of capital are simply managed by the state in different ways than they were prior to the mid-seventies. In fact, economic liberalism, social democracy, 'actually existing socialism' and Third World developmentalism have all relied (and, insofar as they still exist, still do) on the state (or supra-state-like institutions) to manage economic forces, as it was held that no other entity could possibly do so.

Today, such state management simply means the management of the economy by the state in the interests of capital in a manner which is in all essentials equivalent to 'private sector management'. Such management is today primarily biased towards financial interests, while restraining, incorporating and otherwise softening the impact of popular responses so as not to threaten these interests. The shift from a dominant so-called Fordist 'regime of accumulation' to a more 'flexible' regime in a globalised economy is a dimension of this change, not its supersession (Harvey 1990). Imperialism and neo-colonialism have taken different more complex and more diverse forms in today's 'globalised' world, they have not disappeared. It follows that if we are to consider development as an aspect of human emancipation, it must be thought differently today, and not abandoned to the market which can only 'emancipate the few' - an obvious contradiction in terms as the idea of emancipation has to be universal to have any meaning. 
If neither the state nor the market are emancipatory, the challenge then is to help to rethink development in a non-statist and non-economistic manner, and perforce to rethink politics in a manner that is not state-focused, despite the unavoidable importance of the state and its institutions in the field of politics. To detach development from its foundations in both the state and in the economy, to think of it as truly political - i.e. as emancipatory - is the major yet necessary challenge without which we cannot move forward in Africa today. I can only hope to make a very small contribution to this thinking here.

\section{Development and freedom}

The idea of an economic prerequisite for freedom, was of course central to the notion of progress in whichever ideological configuration it took, liberal, social-democratic or 'Marxist-Leninist' (where it took the form of the 'primacy of the productive forces'). The corollary of this ideology of the primacy of economic development was the central role of the state in the process. In capitalist societies, the state was either to manage change so as to maintain order as in the case of the various forms of liberalism, or to mitigate the unequalising effects of the market as in the case of social-democracy, or both (Cowen and Shenton 1996). The 'progress', which nineteenth century thought maintained could be realised through the teleological unfolding of history, was held by twentieth century thought to be realisable in the "here and now' via an act of will through control of the state (or the 'commanding heights' of the economy or a number of variations on the same theme). This overwhelmingly voluntarist perspective was therefore not unique to developmentalism (whether in Africa or elsewhere in the Third World), but permeated the whole of twentieth century thought, even beyond the confines of development theory as Badiou (2005a) has clearly shown.

However today, the temptation often exists to re-varnish the tarnished slogans of social democracy, to bring back (perhaps a slightly modified version of) the post-war European social democratic model and even 'rediscover' the long lost writings of the revolutionaries of the eighteenth century such as Tom Paine (see Stedman-Jones 2004). The South African state is currently refurbishing the 'developmental state' model and seeing Malaysia as its (democratic?) model. Notions of the 'public good' or 'social citizenship' are resurfacing along with arguments on the need to spend state resources on infrastructural projects, while the 'social responsibility' of big capital is touted as an important component in 'public-private' partnerships. While neo-liberalism has not yet been abandoned, there seems to be a serious seduction of many by these formulations, as they seem to presage some kind of alternative to the extreme crassness and highly exploitative character 
of Western neo-liberalism. However, an economic critique of this liberalism is clearly insufficient; if a critique of its politics is not undertaken, such purported alternatives could end up being an expensive error for thinking/developing an emancipatory alternative.

In both Europe and in Africa (and probably worldwide), the politics of the twentieth century were the politics of states and parties and the dominance of economic thought over politics, as the latter was usually reduced to (class) interests expressed by parties and the state. While the colonial state attempted to overcome its economic problems at home by 'developing' its colonies, especially post 1945 (Cowen and Shenton 1996), in post-colonial Africa the same colonial statist practices were continued paradoxically in order to overcome economic dependence. The same coercive and exclusive politics against the working people were now justified in terms of building a nation. In very few cases were attempts made to free and encourage the creative possibilities inherent in the people.

Not only did the state dominate development, it did so by subsuming popular-national interests to western ones and thus reproducing neo-colonial structures and practices. Capital accumulation did not only take place via the plunder of state resources, it did so in compradorial ways (Shivji 1985). While the state managed class (and other) struggles either through outright coercion (forced removals, labour, cultivation, dispossession etc. the idea was either for the state or market to 'capture', in the formulation made famous by Hyden, those beyond their power in order to increase the rate of exploitation. Development then was thus contradictory from the very start, it was concerned to increase the welfare of the population through achieving economic growth, but given the paucity of technology, that growth could only be achieved fundamentally through what Marx had referred to as the 'formal subordination' of labour to capital - an increase in exploitation through physical means. It increased capital accumulation primarily through dispossession, therefore as has been mentioned on numerous occasions, the state took a direct part in the coercive character of production relations (Mamdani 1987).

Today the state has delegated (or perhaps better sub-contracted) its development management functions to external bodies such as NGOs. These are frequently simply new parastatals and simultaneously vehicles for social entrepreneurship for a 'new' middle-class of development professionals. The activists of yesterday have largely joined the state, not necessarily directly, but by becoming subsumed within the new mode of rule through 'civil society'. Activism has been replaced by professionalism. 'Feminism' and 'empowerment' for example, have often been transformed from being popular struggles and demands, to being professions. We have now a new mode of 
state rule which forms the context for re-thinking development. Central to this new mode of rule is the hegemony of human rights discourse and the incorporation of NGOs into the state either directly by turning them into parastatals, or by subsuming them within a state domain of politics.

If we attempt to analyse the process of transformation and development from an emancipatory perspective, which is what I am arguing we should do, a crucial lesson has become apparent today, namely that the state cannot emancipate anybody, or at least no more than a select few. Why? For a number of reasons of which I only wish to mention three core ones here.

First, because state subjectivity is invariably bureaucratic and founded on a managerialist ideology. Today that managerialist ideology is identical to that of private corporate interests (so-called 'private sector management') and a specific 'public sector management' (or 'public administration'), which had suggested some specificity in particular concerning a certain social responsibility by the 'public service' towards 'the public' seems to have been pushed aside. Irrespective of the specific character of managerialism today, the latter is a feature of the state in general, of all states without exception and therefore has, in truly democratic conditions, to be counterbalanced by popular democratic pressure. This feature is simply the result of the fact that the foundation of the state is precisely control and regulation, and that the state sees itself as rightly holding the monopoly of power and knowledge and not only of the deployment of violence. At best therefore in its management of social change, all the state can do is to substitute itself for popular struggles and independent popular organisations, all in the name of the monopoly of knowledge and/or the maintenance of social stability. To avoid misunderstanding, it should be stressed that I am referring here to state 'modes of thought', in simpler terms to 'subjectivities'. All this is to be clearly distinguished from possible structural or other contradictions within the state between different institutional or other interests, or indeed from state provisioning or the enactment of progressive social legislation. Moreover it should perhaps be reiterated that the state (institutionalised power) is in no way, either conceptually or politically, to be reduced to the government. Sociologically, I would include private security firms as well as the mainstream press within the state, the former within the repressive and the latter within the ideological state apparatuses (Althusser 1971; Poulantzas 1978).

Second, because the state systematically transforms a pre-existing emancipatory politics into a technical process to be run by professionals (planners, economists, lawyers, judges, administrators, etc.) under its ambit within bureaucratic structures and subjectivities. This amounts to a process of depoliticisation of say a popular nationalist or revolutionary politics. In sum, the state systematically evacuates politics from state life in favour of tech- 
nique. In addition, under liberal democratic systems, politics is reduced to voting which itself becomes simply a question of numbers to be predicted, counted and analysed by professionals. This process is a highly complex one but ultimately universal in its fundamentals. It also includes, in today's parlance, the institutionalisation of rights fought for by people and their transformation into 'human rights' to be defended and delivered by the state itself (Neocosmos 2005).

Third, because evidence overwhelmingly suggests that it is the state (along with corporate, bureaucratic or communitarian interests) in whatever form and irrespective of ideology, which is and has universally been the main threat to genuine democracy; and that the latter has only been won by hardfought popular struggles by workers, peasants, women and all the multitudes of the oppressed throughout the world. Thus, while it is important for state power to be divided between various mutually controlling institutions and 'powers', it is ultimately only the people who can be the fundamental guarantors of freedom and democracy, not a constitution or the judiciary. In Africa the examples are legion of cases whereby the people never rose to defend democratic constitutions subverted, undermined and finally overthrown by rulers in search of uncontrolled power, simply because these constitutions had lost the confidence of the people, due to their evident manipulation and corruption by politicians, or to their simple exclusion of popular concerns.

To stress that the state cannot emancipate does not mean either that the state is not of use in the development process or indeed that it is absent from the sphere of politics altogether. In actual fact, during the first phase of the post-colonial state (1960s-1970s), that of developmentalism, although a national emancipation project may have failed because of its exclusion of large sections of the population, at least some state project was in existence, a fact which is no longer the case today. Despite its problems, the necessity of supporting that programme at the time cannot be denied, while in fact its origins were precisely in an emancipatory vision. The best way of stating this point is simply to note that state-led emancipatory projects are simply obsolete today. In fact, today we have completely to re-invent emancipatory politics, as such a conception has simply disappeared from thought. Thus, reminding ourselves of the emancipatory vision of pan-Africanist struggles for development in the early life of nationalism is crucially important for the recapturing of such a vision. It is to this vision that we must be faithful, and not to a fetishism of state power.

In sum then, the question we have to pose ourselves is: if indeed the state cannot emancipate anybody, how is emancipation and perforce emancipatory development to happen? Clearly the market cannot do so and no one 
believes it can, so how? Can development be thought of as an emancipatory project today? I want to discuss one way of addressing this issue and the connection between state, development and emancipation through a brief look at the work of T. H. Marshall and the experience of European, particularly British, social democracy.

\section{Social democracy and social citizenship}

It is useful to start with the dilemma which was central to classical sociological thought, namely that the fundamental problem of the maintenance of any society was to combine state authority on the one hand with a moral community on the other. While political theory was concerned with the management of social change by the state in order to maintain stability (Cowen and Shenton 1996), classical sociology was concerned with the existence of a 'collective consciousness' in Durkheim's sense, which would set the commonly agreed parameters of social life in the nation. While in turn of the century sociology, the notion was accompanied by a heavy dose of social pathological and religious arguments, this does not diminish the argument's significance for the contemporary world. For example, it is this moral community which is seen as able to provide the conditions for a consensus in the public sphere according to which recourse to violence would be excluded from the public arena. This idea of 'wanting to live together' (le vouloir vivre ensemble) finds resonance today among advocates of human rights discourse. It refers to consensual politics and is central to the liberal political philosophy of Hannah Arendt (Arendt 1982).

The development of such a moral community could not, for classical sociology, be a simple state imposition, but had to be present within the whole fabric of society. This is quite contrary to today's neo-liberal discourse for which moral community can be built through constitutionalism, the rule of law and the overall legitimacy of the state. These features of liberal democracy simply amount to restrictions on state politics at the level of the state itself; wider society is excluded from holding the state directly to account except through organised interests in civil society, a fact which does not necessarily imply consensus. Ultimately, the whole of society can only have a say on which members of the elite are in power at election time, but not on the character of the state as such. The African experience from the colonial period onwards has been one of state coercion, little legitimate authority and the attempt (when it happened) to build a moral community through state ideology of one form or another. The only conception which comes close to measuring up to a moral community today is no longer sought within African popular culture, but within what is sometimes termed 'a human rights culture' imported from the West (Mutua 2002). 
T. H. Marshall was quite unique in laying out the link between human rights and development within what was the dominant paradigm of social democracy in the post-war period. What is interesting about Marshall's writings is not only his serious commitment to a genuinely social democracy, in which the negative effects of market capitalism on the working masses could be fundamentally countered by state social spending, but also his belief in 'progress' as leading to equality, an equality which he saw as embodied in citizenship. Of course, this was supposed to be a political and not an economic equality, that is, an equality of citizens in relation to the state, itself constructed by the state. A double dream in capitalist conditions, yet in conditions of post-war economic boom and of full employment it made sense, especially during the statist social optimism of the period. This optimism saw an end to the seeming linear succession of civil, political and social rights, this end being largely equated with 'the more equal society of the future' (1964: 346). Such a future was being realised in post-war Western Europe with the setting up of 'welfare states'. 'Social rights', which these were meant to deliver, were 'the rights to an acceptable standard of economic welfare, to health and [...] to education' (1964: 290). Although these rights would not lead to a totally egalitarian society, after all inequality was required to spur the working classes to work harder, the idea was to produce a 'free and independent working class, protected and sustained by their basic rights as citizens' (ibid: 287). The idea then was to create an inclusive society, in which everyone would benefit from citizenship rights and thus 'be accepted as full members of the society' (p. 78). In this way, 'the inequality of the social class system may be acceptable provided the equality of citizenship is recognized' (ibid). 'Citizenship has itself become, in certain respects, the architect of legitimate social inequality' (p. 77, emphasis added). However unless it could transform itself, he saw the 'welfare state' as being threatened by (Galbraith's notion of) the 'affluent society'، Such a society, Marshall argued, was the antithesis of welfarism, as 'it looks eagerly for windfalls' from speculation legal or illegal, 'bogus expense accounts, football pools, premium bonds'; the latter 'was based on the opposite principle. It did not reject the capitalist market economy, but held that there were some elements in a civilized life which ranked above it and must be achieved by curbing or superseding the market' (ibid.).

He continued despondently by noting that: "what is more disturbing is that the Affluent Society does not appear as yet to have a soul at all, either to lose or to look for, and it is unaware of what it lacks' (ibid: 302). Now that we have seen the disastrous effects of the development of this 'affluent society' which we now refer to as neo-liberal capitalism, we need to go beyond Marshall's thinking. In fact his perspective is limited by a number of factors 
which we are much more aware of today from our historical and geographical vantage point in Africa.

Nevertheless, what should be noted here is not so much the obvious attempt to legitimise class oppression (as has been mentioned at length) - an oppression evidently sustained by the state - but a double conception of the importance of state legitimacy, a notion itself central to classical sociology: first the subtle understanding of the necessity of a moral order for a necessary commitment to the system, so that the poorer sections of the national community can develop a stake in it; and second the locating of this stake in the rights of citizenship. This method of resolving the problem, which I identified earlier, between state power and a societal moral order, was addressed in a specific way by European social democracy. This way was made possible partly by the specific ways in which Fordist capitalism combined accumulation, exploitation, consumption and full employment policies with the role of the state as a virtual monopoly of welfarism, as I have already mentioned.

Interestingly, in hindsight, Marshall also made a number of remarks concerning 'voluntary societies', by which he refers to what we call today NGOs, which are worth repeating. He notes for example that 'representative government alone will not create a true democracy if the citizen cringes before the official, or if he sullenly resents his authority' (p. 348). What he sees as a solution however is 'co-operation between statutory and voluntary services' (ibid) and this despite the fact that he realises that there is fundamentally no distinction in their forms of operation between statutory and voluntary bodies and associations, and moreover that these voluntary agencies only have a 'moral responsibility' towards their clients as they are not directly representative - they have 'no such constituency' (p. 349) - particularly as 'voluntary supporters' gradually become replaced by 'professional employees of the society' (p. 350). After all he notes: 'voluntary action is part of public policy' (p. 353) and 'the state must have the final word' (p. 355). These observations are more sophisticated than many we hear today regarding NGOs; the conclusion we can draw from his argument is that voluntary NGOs have clients and operate for the most part on the basis of a subjectivity which is identical to that of the state. Marshall does not believe that (liberal democratic) state practices are in any way oppressive, hence his failure to consider genuinely popular organisations in his argument.

\section{Social citizenship in Africa today}

We can agree with Marshall that social citizenship is the solution to the problem of reconciling state legitimacy with a moral community. Yet today, economic provisioning cannot be put before popular politics because we live at 
a time of economic crisis which has overtaken the conceptions of full employment, mass consumption and welfare provisioning which characterised Fordist-cum-social democratic/Keynesian forms of accumulation, as well as developmentalism in the post-war period. Mass unemployment and mass poverty are seen today as unavoidable features of contemporary capitalism. A return to classical social democracy is unlikely if not impossible within the current global socioeconomic context. The populations of the world can therefore not be so easily convinced to defer or abandon their direct political rights of citizenship through the provision of economic welfare, state social infrastructure and high standards of living; these are simply absent for the majority in conditions of hegemonic market subjectivity. In any case if we are to remain faithful to an emancipatory conception of development, this can no longer be conceived as statist. Today if it is to have any meaning, social citizenship must be provided with a fundamentally different content.

What is very interesting to note, is the common prevalence of conceptions of the necessity to develop a moral community politically among many of the popular movements against the oppression of colonial as well as postcolonial states. In fact, this notion, although not always understood in an identical manner, contains the leitmotif of an identification of 'moral community' with a community of active citizens. In other words it could be suggested that a common feature of popular opposition in Africa has been precisely the understanding of moral community as an active citizenship of political agency, whereby ordinary people seem concerned to oppose to the clear immorality of the state and colonial/market culture, a different conception of morality in which active citizenship plays the key role. Indeed it could be argued that it is this conception of active citizenship which has the character of a true democratic universal, not the passive citizenship of human rights discourse which is dominant today.

We can see from an analysis of the trajectories of struggles for independence in Africa, what happened throughout the world at different periods. This could be termed a shift from rights to human rights, a shift from an inclusive moral community of active citizens in a period of struggle for independence, to an exclusive essentialist community of passive citizens after independence. This can be seen in the case of one of the first struggles for independence in Africa and in one of the last, in Algeria and in South Africa. In the former case Fanon's $(1989,1990)$ analyses portray a clear distinction between a period of popular upsurge against colonialism, where people become transformed into active citizens taking their own destiny in hand, and a post-independence period, when they become passive citizens of the state, approving of the chauvinism which systematically excludes foreigners (to begin with). I have outlined very similar processes in the South African case 
in my own work, with the added importance of the Truth and Reconciliation Commission in transforming South Africans from political agents in the 1980s to supplicant victims in the 1990s (Neocosmos 1996, 1999, 2006). In both cases we can see a transition from an active popular conception of citizenship which is largely inclusive in perspective, to a passive state-imposed conception of citizenship as indigeneity which is exclusive of the growing number of 'others'. The fundamental reason for the change in either case is the collapse or defeat of an independent popular emancipatory politics.

Understanding the transition in this way illuminates some of the links between state power, active citizenship, and the moral order necessary for national emancipation, and displaces 'human rights discourse' from its position of uniqueness, to being only one particular (statist) conception of politics. It therefore contributes to a necessary critique of liberalism. If in wishing to understand the transition from colonialism/apartheid, we remain at the level of the state/party/organisation, the shift is invisible, which is what the re-writing of history by the state after liberation attempts to do in order to show a linear continuity. A human rights culture - the hegemony of human rights discourse - can thus be understood as part of the process of production and reproduction of what Badiou calls the 'capitalo-parliamentary' system, that is, the liberal state which simply manages capitalist interests. In those countries where human rights discourse is being resisted by the government, it nevertheless provides the main ideological support for an oppositional perspective, in this way authoritarian systems provide a main source of subsistence for liberal democracy.

Citizenship, from an emancipatory perspective, is not about subjects bearing rights conferred by the state, but rather about people who think about (who are capable of truths in Badiou's sense) becoming agents through their engagement in politics as militants/activists and not as politicians. In fact it is important to understand how this stress on political agency was central to popular struggles and how it is still prevalent among many popular movements today. For example, Fanon's Studies in a Dying Colonialism is a detailed investigation into different examples of change in social relations brought about by popular struggle. These include changes in the position of women in society, the effect of independent radio stations, and changes in the family.

In other words, the point is that during the period of popular national upsurge, citizenship as a unifying, inclusive conception, as a community of active citizens, is being born. No distinction is made between people on the basis of indigeneity but only on the basis of their devotion to the struggle. By the time he writes The Wretched, we have the following well known account of xenophobia under the post-colonial state: 
On the morrow of independence [the] native bourgeoisie ... violently attacks colonial personalities... It will fight to the bitter end against these people "who insult our dignity as a nation". It waves aloft the notion of the nationalization and Africanization of the ruling classes. The fact is that such actions will become more and more tinged by racism, until the bourgeoisie bluntly puts the problem to the government by saying "We must have these posts" (ibid: 125).

We have here an account of a clear transition between the two forms of citizenship I have referred to: the popular inclusive conception founded on active citizenship and the state conception founded on indigeneity and passivity. It is also important to note the similarity with work on the South African struggle of the 1980s which makes similar points regarding the character of popular struggle in this period (Neocosmos 1998; Van Kessel 2000). The point is not to idealise popular struggle but to note that, despite all its contradictions, it enables the development of a different conception of citizenship.

\section{Can a 'human rights culture' enable active citizenship?}

Development today is regularly used along with names such as 'participation' and 'human rights'. Indeed it seems impossible to think of popular politics outside the parameters of the discourse of human rights. The language is pervasive in the societies of the South and seems today the only way in which human emancipation can be conceived, simply because human rights discourse provides the parameters through which people in communities resist oppression and assert their rights vis-à-vis the depredations of authoritarian states and capitalist interests. Yet at the same time, 'human rights' language is also the language of the new form of imperialism, the justification, inter alia, for the invasion of Afghanistan and Iraq and the slaughter of countless civilians in the process. Human rights and participation is also central to the language of the World Bank and is in danger of becoming, in the formulation of one recent publication, 'the new tyranny' in development (Cooke and Kothari 2002). How are we to make sense of this contradiction? Does human rights discourse enable or disable the active citizenship which I have argued must be put at the centre of our thinking today? These are some of the questions in dire need of answers. I shall propose a way of approaching them in what follows. I shall try to deal with these issues, admittedly superficially, under two main headings: the relationship between human rights discourse and political passivity, and the role of human rights discourse in imperialism today. Both are closely related because human rights discourse is fundamentally a-political. 


\section{Human rights discourse and passive citizenship}

Human rights are said to be realised within what is referred to by neo-liberal discourse as 'civil society'. Civil society in the literature is usually equated with NGOs, but this excludes organisations which operate at the margins of legality or which are totally 'informal'. It excludes politics outside a domain formally recognised by the state. Civil society is better understood as a domain of politics over which the state attempts to exercise its hegemony. This attempt is often successful (otherwise civil society is said not to exist) despite the possible contradictions between government and specific NGOs. It is in civil society that citizenship rights are said to be realised, however these are to be realised in a manner which keeps them firmly away from any (emancipatory) politics which question the state itself as they take place within the framework of 'human rights'. However, before addressing this issue, it is important to stress the fact that civil society is not the only realm of politics outside the state, and moreover it is possible to suggest that civil society in Africa today forms a realm of politics which is dominated by the state itself. To put the point simply, the politics of civil society are state politics, for it is the state which pronounces on the legitimacy of the organisations 'of civil society'.

However, from the perspective of a democratic emancipatory project, the state should not be allowed to dictate whether popular organisations are legitimate or not, and neither can intellectual inquiry allow itself to narrow the concept to adhere to state prescriptions; only society itself should be entitled to bestow such legitimacy. In this sense South Africa for example, can be said to have had an extremely powerful and 'vibrant', as well as politicised, set of popular organisations in the 1980s but these never formed a 'civil society', and were not described as such at the time because of their quasiillegal nature and their illegitimacy in the eyes of the state. In fact, it was precisely the political distance of these organisations from the state, the fact that they had exited the state domain of politics and operated beyond the (obviously restricted) civil society of the time, which accounts for the 'vibrancy' of such popular organisations in the South African townships of the 1980s (Neocosmos 1998, 1999). Conversely, it can also be pointed out that the neo-liberal conception of civil society also implies recognition by civil society organisations of the legitimacy of the state. This view cannot include explicitly revolutionary organisations within civil society. For such a viewpoint therefore, these same opposition organisations in South Africa in the 1980s (UDF, Civics, Youth and Women's organisations etc.), which were fighting the apartheid state as such and which were thereby constantly testing the limits of legality (their activities were often wholly illegal), could not be rigorously said to form a 'civil society'. Indeed they were only described 
in such terms in the 1990s, when the state had no option but to recognise their legitimacy in the eyes of the people.

For neo-liberalism therefore civil society exists solely under conditions of mutual recognition between it and the state, only under liberal democracy. It is this mutual recognition which defines the parameters of the state consensus and is itself the result of struggle. Moreover, it is the state which retains the monopoly of national universality. Civil society organisations can be tolerated but only if they represent particularistic interests. Any claims to such universality, in other words if a popular organisation is said to represent 'the people's interests' or 'the national interest', would mean that it is liable to be seen by the state as a threat to its monopoly of universality. A state 'national' consensus is structured within a state domain of politics comprising the political relations between the state and its institutions on the one hand, and the 'official' or 'formal' civil society of citizens on the other. Other forms of politics by unrecognised organisations are seen as beyond the consensus and can thus be de-legitimised in state discourse. These organisations and politics therefore exist outside or beyond the limits (at best at the margins) of civil society. Because of such partiality therefore, 'civil society' cannot be conflated with 'organised society' as the term necessarily implies some form of exclusion (Neocosmos 2004). The distinction between liberal democracy and say colonial/apartheid forms of authoritarianism can be said to concern inter alia the extent and forms taken by such exclusion.

Simultaneously this mutual recognition is given substance by 'human rights' which are visualised as formal and universal (that is, ahistorical and a-contextual), and therefore not subject to debate or contestation because they are deemed to be scientifically, technically or naturally derived. Civil society today is said to be the realm within which human rights are realised or expressed. These rights, even though fought for and achieved through popular struggles throughout society, are supposed to be 'delivered' and 'guaranteed' by the state. They are taken out of popular control and placed in a juridical realm, where their fundamentally political character is removed from sight so that they become the subject of technical resolution by the judicial system. Human rights, therefore do not only depend on a spurious Western philosophical humanism of 'Man' for their conception, an ideology through which individuals are 'interpellated as subjects' by the state itself (Althusser 1971), they also represent the de-politicisation and technicisation of popular victories under the control of the state. The people are forced, if they wish to have their rights addressed and defended, to do so primarily within the confines of, or in relation to, the state institutions of the judiciary.

Thus, even though 'rights discourses can both facilitate transformative processes and insulate and legitimise power' (Krenshaw 2000: 63), the poli- 
tics of human rights is, at best, a state-focussed politics and is predominantly reduced to a technicised politics, which is limited to a demand for inclusion into an existing state domain. Thus a struggle for rights, if successful, can end up producing the outcome of a fundamentally de-politicised politics. In fact it could be asserted abstractly that, while in pre-liberal writings and practice the state expressed the will of God, in liberal writings and practice, the state expresses the will of Man; freedom simply consists in obeying that will (Althusser 1971). In sum, technique and science (the bearers of which are experts and state expertise) are in this manner unavoidably abstracted by the state from the socio-political context and conditions which alone give them meaning, and thus acquire a life of their own, independent of that context and those conditions. To be accessed by ordinary people and democratised, they need to be re-politicised and their technical quality shown to be, at best, only partly independent of socio-political content (Foucault 2000).

It has been rightly mentioned on many occasions - this was the essence of the Marxist critique of 'bourgeois rights' - that the poor and oppressed were systematically excluded from exercising their rights because of unaffordability, lack of knowledge and access to all the resources which (bourgeois) state power monopolises and which are necessary for the realisation of rights. Equality of rights it was stressed, was simply impossible in an unequal society. Therefore the supposed universality of rights was fallacious as the 'human' in human rights (as indeed the idea of 'Man' as a transcendental human subject) was in fact, the Western, white, bourgeois male.

If human rights discourse contributes to the maintenance of privilege for the privileged and to the exclusion of the oppressed majority from state politics, it also has the effect of absolving the latter from the responsibility of engaging in political activity themselves. This is because it is maintained that some external body such as the judiciary (or the criminal justice system as a whole), the health system, an NGO, political party or whatever - in other words a state institution - will resolve the political issue at stake on their behalf. As, for example, the judiciary will only deal with individualised subjects and not with the historical context of social structures, issues concerning power relations are rarely raised. Moreover, given that the greatest threat to rights comes from the state itself, we have the interesting phenomenon of one state institution (usually the judiciary, its members unelected and unrepresentative) being charged with defending people's rights against other state institutions; the state is thus meant to police itself, this particular right is removed from the people.

The whole system, both materially and culturally, thus has the effect of excluding the majority from official state politics on the one hand, while making it difficult if not impossible for them to mobilise politically on the 
other. It amounts to a permanent system of political de-mobilisation and disempowerment - a process of fundamental de-politicisation of the majority (Englund 2004). It leads to and sustains the complete antithesis of an active citizenship which is the necessary basis of democracy and gives a whole new meaning to the expression: 'the rule of law'. Non-citizens, despite the setting up of juridical structures such as international courts, are regularly excluded from rights which can only be claimed through one's 'own' state. Thus, despite the liberal view that it is universal human subjects who are the bearers of rights, these can usually only be accessed by 'citizens' of a state, as it is the latter which bestows that status upon them (Mamdani 1995). Of course, the apparent benefits of citizenship, as feminist scholars in particular have noted, are differentially distributed, as the powerless are much less able to secure them (Yuval-Davis and Werbner 1999; Hassim 1999).

The effects of political dis-empowerment and the consequent political passivity must not be understood as restricted exclusively to civil life, as they permeate deeply into the constitutive social relations of the fabric of society itself, as the authoritarianism of social structure replicates and makes possible the authoritarianism of state power (Foucault 2000). This is particularly obvious in conditions of post-coloniality in Africa, conditioned as these societies are by the authoritarian legacy of colonialism and apartheid. It is quite unsurprising then that personal responsibility based on power, and control inter alia over education, housing, work let alone over desire, sexuality, knowledge as well as over self or personhood, is quite simply lacking. Neoliberalism, which provides the socio-political passivity of empty choices without power, and abysmally fails to even consider the conditions and capacity for its own induced or interpellated subjects to make responsible subjective decisions, is itself the ultimate ideological source of child-like powerlessness. The simple fact that state (or other) power is expected to decide on one's behalf, and that this is systematically internalised in the process of identity formation, is arguably what lies at the root of issues of powerlessness as disparate as those of HIV-AIDS, the alienation of youth from society, the absence of people-centred development and poverty. Conversely and happily for the state, the 'commonsense' apparent 'obviousness' of the immutable absence of a capacity to make such decisions, means that an even weaker 'other' can always be found to provide a simple and obvious answer to one's powerlessness in those cases where the intervention of power, in whatever form (state institutions, market, NGOs, family, etc.), fails to live up to expectations which it has itself cultivated. Xenophobic violence, violence against women, children, babies, the elderly and so on (the weakest sectors of society), as has been noted on innumerable occasions, is closely linked to powerlessness. 
Paradoxically then, a rights discourse purportedly concerned with providing the enabling environment for freedom, within the context of liberalism in a post-colonial society, fundamentally and systematically enables its opposite - political and social dis-empowerment - through the hegemony of a state-centred consciousness. Today even state politics is reduced to management; after all what is 'good governance' if not efficient management and administration? At the same time we must remember, as I have already noted, that the distinction between public and private sector management has been largely obliterated; it is the latter which dominates today; this we are told is an effect of 'globalisation'. 'Good governance' and even 'popular participation' in hegemonic discourse, simply refer to the most capital-friendly management techniques possible (Taylor 2002).

Having systematically de-politicised the population and systematically disabled their engagement in active politics, state agencies and politicians can then regularly emphasise the 'irresponsibility' of allowing too much free expression and organisation as this would lead to support for demagogic politics, for capital punishment, xenophobia, racism and so on. In other words, having produced political passivity, illiteracy and ignorance, these are then used as justifications for placing restrictions on democracy by calling on 'enlightened despotism' from those in power-much as under apartheid and colonialism, state-induced ignorance among the oppressed was used as a justification for the maintenance of colonial power. In sum, liberalism in post-colonial Africa systematically militates against the formation of a moral community of active citizens, in other words against the construction of a political community properly understood. In the absence of political agency given the hegemony of political passivity, political choices cannot be made by the overwhelming majority, and political morality disappears; these are of course the necessary conditions for political exclusion and violence. The miserable moralism of 'human rights discourse' is fundamentally part of these conditions. Human rights discourse then is an obstacle to active citizenship and especially to the development of emancipatory politics; 'human' rights are and can only be understood as institutionalised rights.

In Africa generally the technicisation of politics, the evacuation of politics from the state and its replacement by managerialist ideology, has meant the exclusion of the majority from active citizenship and the structuring of a state and elite consensus around political illiteracy and passivity especially as the state concurrently 'naturalises' its dominance and technicism. We are told that there is no alternative to the way things are done, for this is natural and in conformity with the consensus of the scientificity of state activity. Moreover, civil society in Africa, the realm of rights, has become, sociologically speaking, a middle-class phenomenon which provides employment and 
opportunities for social entrepreneurship for professionals and members of the elite who, as a result, are the only ones to acquire the full benefits of citizenship (Kanyinga and Katumanga 2003). Gramsci's (1971: 263) formulation 'the state $=$ political society + civil society' appears particularly apt under such conditions.

\section{Human rights discourse and the new imperialism}

In a different context, Chatterjee also stresses the role of international NGOs in spreading human rights discourse which, he argues, forms one of the main pillars of imperialism today. It is important to stress these points here as they are constitutive of the currently hegemonic conception of democracy and human rights. It is important to recognise that in the new form of imperialism - which does not have a clear centre - it is not simply that the power of governments to make decisions on their own economies is undermined, even perhaps more importantly, national sovereignty is being undermined by human rights discourse. This takes a number of forms including the trial of gross violators by the International Human Rights Court in the Hague (so that they are not accountable to their own people) and the propagating by international NGOs (Oxfam, Médecins sans Frontières etc.) of Western conceptions of human rights. It is clearly in this way that the foundations of empire are being laid. The connection between imperialism and human rights is explained extremely well by Chatterjee:

Liberals are now saying that $[. .$.$] international law and human rights must be$ established all over the world. Where these are violated, the guilty must be punished, without undue regard for the privileges of national sovereignty. If the leaders of states themselves have little concern for the law, if they themselves ride roughshod over the human rights of people, then why should the excuse of national sovereignty be allowed to come to their rescue? In that case human rights would never be established. What is needed, therefore, is the drafting of a global code of state practice and the creation of international institutions to monitor and implement this code. On what authority will these international judicial institutions be set up? Bodies run on the principle of one country one vote, such as the United Nations General Assembly, will be utterly inadequate to the task. The liberal democratic countries must come forward to accept their responsibility in creating the institutional space for the operation of an ideal global sovereignty. The name for this sovereign sphere [...] is empire (2004: 98).

Of course, if the responsibility of 'Western democracies' extends to ensuring that democracy and the rule of human rights is to be accepted throughout the world and if there is any (obviously misguided) resistance to such acceptance, then democracy and human rights must be imposed by force if necessary. 


\section{Chatterjee (2004: 100) continues:}

The theorists of the new empire have talked of still more wonderful things. This empire is democratic. It is an empire without an emperor. The people are sovereign here, as it should be in a democracy. That is precisely why this empire has no geographical limits. This is not like the empires of old where territories have to be conquered by war to add to the size of the empire. Now empire expands because more and more people, and even governments, looking for peace and for the lure of economic prosperity, want to come under its sheltering umbrella. Thus empire does not conquer territory or destroy property; rather, it encompasses new countries within its web of power, makes room for them in its network. The key to empire is not force but control. There is always a limit to force; there is no limit to control. Hence empire's vision is a global democracy [...] We can see the exercise of control right in front of our eyes [...] Even such a deeply political matter as punishment for alleged violations of human rights has now become the jurisdiction of new international judicial institutions. The trial of Milosevic is the most dramatic example of this.

However this is not all. While supra-national courts such as the European court of Justice or the International Court of Justice in the Hague are set up by agreement between states in multinational fora such as the UN, there is also another much more subversive and insidious aspect to the establishing of the hegemony of human rights discourse: the operations of so-called 'international civil society'. Chatterjee continues:

If the protection of human rights is a function of empire, then that task is being carried out not simply by the international courts. It is being done daily, and diligently, by numerous such international NGOs as Amnesty International, Médecins sans Frontières, or Oxfam, whose able and committed activists probably have never suspected that they are, like little squirrels, carrying the sand and pebbles that go into the building of the great bridgehead of empire. But that is where the ideological foundations of empire are being laid (pp. 100-1).

As Mutua explains, 'although the human rights movement arose in Europe, with the express purpose of containing European savagery, it is today a civilizing crusade aimed primarily at the Third World [...] Rarely is the victim conceived as white' (2002: 19, 30). And Badiou continues:

Since the barbarity of the situation [of victims in the Third World - MN] is considered only in terms of 'human rights' - whereas in fact we are always dealing with a political situation, one that calls for a political thought-practice, one that is peopled by its own authentic actors - it is perceived, from the heights of our apparent civil peace, as the uncivilized that demands of the civilized a civilizing intervention. Every intervention in the name of a civilization requires an initial contempt for the situation as a whole, including its 
victims. And this is why the reign of 'ethics' coincides, after decades of courageous critiques of colonialism and imperialism, with today's sordid self-satisfaction in the 'West', with the insistent argument according to which the misery of the Third World is the result of its own incompetence, its own inanity - in short, of its subhumanity (Badiou 2001a: 13).

And even more directly:

The refrain of 'human rights' is nothing other than the ideology of modern capitalism: we won't massacre you we won't torture you in caves, so keep quiet and worship the golden calf. As for those who don't want to worship it, or who don't believe in our superiority, there's always the American army and its European minions to make them be quiet (Badiou 2001b: 2-3).

In case anyone doubts this, it is perhaps important to recall how those in power in South Africa so easily swallowed the hegemonic refrain of the equating of human rights with market freedoms, the then minister of trade and industry, for example, stressing that 'the struggle for freedom and democracy in South Africa was substantially advanced by the successful campaign to link trade and human rights' (Erwin 1998: 57). Clearly from a position of power, in a post-authoritarian state it does seem that human rights do 'substantially advance' or 'immeasurably increase' freedom, yet it soon becomes apparent that this 'freedom' is nothing like universal, nor indeed democratic. Even the recent ideology of 'multiculturalism' in plural societies can be seen fundamentally to be a disguised form of racism corresponding to new 'softer' and 'more democratic' imperial relations. Zizek (1999: 216) makes the following observant comment vis-à-vis multiculturalism, one of the offshoots of human rights discourse today, and its affinity with the current form of imperialism usually referred to today by the more benign term 'globalisation':

the form of ideology of this global capitalism is multiculturalism, the attitude which, from a kind of empty global position, treats each local culture as the colonizer treats colonized people - as natives whose mores are to be carefully studied and 'respected' [...] just as global capitalism involves the paradox of colonisation without the colonising nation-state metropolis, multiculturalism involves a patronising Eurocentric distance and/or respect for local cultures without roots in one's own particular culture [...] multiculturalism is a disavowed, inverted, self-referential form of racism, a 'racism with a distance' - it 'respects' the Other's identity, conceiving the other as a self-enclosed 'authentic' community towards which the multiculturalist maintains a distance made possible by his/her privileged universal position.

This is a crucially important remark. Just as there is no obvious centre for capital (or indeed empire as Hardt and Negri 2001 argue) today - capital is literally global - there is no centre for 'multiculturalist' racism and no centre 
for human rights discourse. It is the latter which is the equivalent of multiculturalism in the legal/NGO realm of civil society. Human rights discourse is the new racism, it is the ideological vanguard of the new form of empire; it has been re-discovered and re-packaged by international NGOs, so that popular struggles for rights and entitlements become ultimately transformed into demands for human rights to be delivered and protected ultimately by states and not by people themselves. That is why it is so easy to be convinced by the apparently liberatory character of liberalism, for it seems to provide a vision and theory of freedom. However, it is becoming more apparent that just behind the benign and smiling faces of international NGOs or the humanitarianism of the UN lies the hideous grimace of all out war and the destructive and systematically anti-human power of the US, the only super-power and World policeman (Harvey 2005).

In sum then, the politics of the new imperialism today are the politics of neo-liberal 'democracy' and human rights. This is why it is fundamentally flawed to think that a discourse of human rights has an emancipatory content. Of course, in case activists may start to feel uneasy, I must repeat that I am not dismissing struggles for rights, rather what I am concerned to argue is for a clear distinction between the struggle for rights by people, particularly those with a universalistic appeal, and the requests for human rights from states, NGOs and multinational institutions. In fact when one is struggling for rights against any injustice or oppression, one is exercising active citizenship and asserting one's humanity, when one is appealing for human rights, one is simply exhibiting one's passivity vis-à-vis power. Paradoxically then, it is the second practice which is de-humanising, as it removes agency from people; it is various state institutions that decide the content of humanity, which they simply reduce to politically passive individuals; human rights discourse is thus the antithesis of true humanity as it systematically undermines human agency. There can be therefore no emancipatory politics founded on human rights discourse and proliferating the number of recognised rights in international conventions does not constitute the way forward.

If one wishes to find a way around the contradiction between the oppressive state and the necessity to construct a moral community in Africa, the arguments of social-democracy are no longer helpful. This is fundamentally because they deny the importance of (an emancipatory) politics in favour of the economy and the state (while simultaneously leaving the whole neo-colonial edifice at the global level in silence), thus reproducing, within the context of empire, the eternal and abstract 'danse macabre' between state and market. Both of these have to be made accountable to society, hence the centrality of politics. While the state is definitely an important component of the field of politics, politics can no longer be reduced to the state. A funda- 
mental re-thinking is required, one which places political agency at the foundation of a new social contract between society and state. It is more important than ever that this thinking distances itself from the vulgar money-spinning and miserable moralism of a human rights discourse, which forces people into victimhood, as it has come to constitute a humanism without a project which has discarded human agency in favour of appeals to the state. In the absence of such critique, the language of 'decency' and 'fairness' (Rawls) and that of 'democracy' and 'freedom' (Sen) will remain the empty verbiage it now appears to be in Africa despite the valiant efforts of such thinkers to save it from total corruption.

I shall argue below that emancipatory politics eschews the passivity of victimhood in favour of the construction of political agency. Reasserting the centrality of politics in theory is a difficult enterprise, particularly as (emancipatory) politics is not always in existence and is clearly largely absent at present. Such a re-thinking of politics should arguably begin by stressing the central importance of a moral community of active citizens, drawing on the experience of various traditions and popular movements in Africa and elsewhere as well as on the philosophy of those who attempt to understand politics as human militant activity (for example, Badiou 1998a; Lazarus 1996). In order to recover an emancipatory project of development, it is precisely from an analysis of politics that intellectual work must begin.

\section{Social movements and politics}

Given the collapse of the great emancipatory projects of the twentieth century, social movements are often seen today as the hope for, if not the actual solution to an emancipatory future. Yet social movements alone have not shown themselves to be emancipatory. After all, movements are difficult to sustain over time. One of the core problems of emancipatory struggles has been understood, at least since the revolutions of the eighteenth century (American, French and Haitian), as concerning the linkage between a social movement on the one hand and organised politics on the other. In the twentieth century, particularly since Lenin's What Is to Be Done, this problem has been resolved through the formation of political organisation in the form of parties. These have allocated to themselves the monopoly of political knowledge, while movements provided the impetus and the mass base. Irrespective of their specific ideology, political parties of intellectuals were said to be necessary in order to lead (dominate) the movement and direct it toward the desired outcome. Of course, as parties later melded with the state, the problem of who the party represented, the state or the people/masses, arose in acute forms for those who wished to be faithful to an emancipatory concep- 
tion of politics. Invariably, the contradiction was resolved in favour of the state. Today the party form must be transcended as it is statist in essence.

\section{On political parties}

The failure of social democracy in the West like the failures of the developmentalist project in the South and of 'actually existing socialism' in the East, have forced us to re-think human emancipation. All these were state projects. Central to this new emancipatory project must be a different understanding of politics in which the state is not the source of all wisdom and for which people are capable of exercising thought as active citizens. It seems that in Africa it is only on the basis of such an active citizenship independent of the state that a genuinely national consensus can be achieved and that a civic normative order can be gradually constructed. In the absence of this, only a state-consensus is possible in conjunction with the indifference and alienation of the majority from national formal state politics, as is clearly the norm today where, in addition, political parties have become vehicles for the enrichment of elites rather than links between society and state.

While in Europe this de-politicisation of politics has become evident perhaps since the crisis of social democracy, in Africa, popular disaffection with politicians and hence parties has been longstanding. It has been apparent on the continent that political parties, rather than being links between civil society and the state as maintained by liberal democratic theory, have become state agencies for placing members of dominant social groups into powerful state posts with the consequent reproduction of an extremely powerful and corrupt elite, which is seen quite apparently as accumulating at the people's expense through access to state resources. Parties in Africa often end up being instruments for reproducing sectarianism at the expense of the national interest, so much has been evident since the struggles of the 1980s for the so-called 'second liberation' of Africa (Ake 2002). In actual fact of course, the liberal conception of political parties which sees these parties as links between the state and civil society, is premised on the view that the state domain is the exclusively legitimate domain of politics. If society were itself to be politicised through the expansion of a genuinely popular domain of politics, then it could be that political parties as presently organised become redundant, or at the very least contested as the exclusive form of political organisation.

In fact, Hannah Arendt made the main point, which I am stressing here, long ago, namely that parties must be understood fundamentally as state institutions:

parties, because of their monopoly of nomination, cannot be regarded as popular organs, but $[\ldots]$ are, on the contrary, the very efficient instruments 
through which the power of the people is curtailed and controlled [...] Hence, from the very beginning, the party as an institution presupposed either that the citizen's participation in public affairs was guaranteed by other public organs, or that such participation was not necessary and that the newly admitted strata of the population should be content with representation, or, finally, that all political questions in the welfare state are ultimately problems of administration, to be handled and decided by experts, in which case even the representatives of the people hardly possess an authentic area of action, but are administrative officers, whose business, though in the public interest, is not essentially different from the business of private management (Arendt 1963: 269, 272, emphasis added).

This statement acquires even more relevance today when the difference between public and private management has virtually disappeared. Now, if it is true that politics has been evacuated from political parties and the state and the evidence to this effect seems rather convincing, we need to ask the question of whether politics has now been embodied in NGOs and social movements or whether it has disappeared altogether from social life. In order to begin to approach this question, even before we can investigate it empirically (something well beyond the scope of this paper), we need to construct an alternative to the distinction between state and civil society, a distinction which, because it is embodied in neo-liberalism, is therefore also embodied in state politics, in other words within the problematic of 'governance'.

This can be done by stressing a distinction between different forms and domains of politics characteristic of the state and of the elite/ruling class who are associated with it on the one hand (elite politics, state politics, dominant/hegemonic politics, etc.), and those domains and forms of politics practised by those excluded from and oppressed/coerced by it on the other (popular politics, subaltern politics etc.). This distinction must be undertaken on the basis of the social relations, cultural practices and discourses within which each exists. This is the view taken for example by Partha Chatterjee and his colleagues in India who have analysed the relations between state politics and subaltern politics, and it is the view taken here (Chatterjee and Pandey 1992). Chatterjee (1993: 12) notes for example that, in the case of India, 'each domain [of politics] has not only acted in opposition to and as a limit upon the other but, through this process of struggle, has also shaped the emergent form of the other'.

In general, it can be argued that the fundamental reason for the difference between the politics of the hegemonic groups and those of the subaltern groups in society is related to the role which the state itself plays in each. In particular, the ruling classes and groups establish their hegemony through the state and hence through one form or other of authoritarian, bureaucratic or administrative political practice. These various forms of politics are by 
their very nature state-founded politics, if not wholly étatiste in nature. Such a politics not only restricts democracy in one way or another and to some degree or other but channels it within formalistic exercises which empty its content while retaining its shell. These kinds of politics may differ along a continuum between say liberal democracy and dictatorship, but they always exhibit elements of a bureaucratic or authoritarian practice, simply by virtue of the fact that they are founded on the modern regime of power. The managerialist politics which have become hegemonic in the public spheres of today's liberal democracies, as well as in multinational organisations such as the United Nations and so on, are evident examples of this.

The hegemonic project of the ruling classes or groups therefore is founded on a politics which is structurally and fundamentally undemocratic (irrespective of the complex contradictions between various interests or positions within the state apparatuses), as it has to manage state rule bureaucratically. Its undemocratic nature may be more or less tempered and restricted by popular pressures and especially democratic prescriptions emanating from within society. These subaltern forms of politics emanating from within society are clearly contradictory, including as they do both authoritarian as well as democratic forms of politics and may be expressed in completely different representational forms from those associated with the modern state (religious, 'traditional', literary, theatrical, etc.), but they may possibly form a distinct domain of a counter-hegemonic project (Chatterjee 1993). If it is to be more than a state-centred project, this has to be founded on a populardemocratic politics and thus on a project for the democratisation of the state itself. Indeed it is an argument of this paper, that popular-democratic or consistently democratic politics are the kind of politics which are by their very nature emancipatory and which are of greatest interest to the majority of the people of Africa - the poor and the oppressed. The possibility for the development of emancipatory-democratic politics therefore will tend to be found primarily within the popular domain of politics as, despite the contradictions within it, the domain of state politics is founded on administrative, managerial and bureaucratic concerns, the nature of which is anything but democratic.

In his more recent work, Chatterjee (2004) extends the distinction between state and subaltern domains through expanding Foucault's notion of 'governmentality' which the latter distinguished from other forms of rule such as sovereignty (Foucault 2000: 220). For Chatterjee it was the emergence of 'mass democracies' in the twentieth century in the West which produced an entirely new distinction, that between citizens and populations. While the concept of 'citizen' carries an ethical connotation of participation in the sovereignty of the state and hence of claiming rights from the state, a 
process through which the state secures legitimacy, under 'governmentality' the regime of power secures its legitimacy through:

claiming to provide for the well-being of the population. Its mode of reasoning is not deliberative openness but rather an instrumental notion of costs and benefits. Its apparatus is not the republican assembly but an elaborate network of surveillance through which information is collected on every aspect of the population that is to be looked after (Chatterjee 2004: 34).

Thus, populations do not bear any inherent moral claims. Ideas of participatory citizenship fell by the wayside in the twentieth century and gradually 'the business of government has been emptied of all serious engagement with politics' (ibid: 35). Of course one can see this as central to European social democratic norms and to the state in Africa, where governmentality had predated the existence of the nation state under colonialism, along with what Cowen and Shenton (1996) have called 'trusteeship'. The latter was the idea that an agency, in this case the state, sees itself as entrusted to act on behalf of others for their own benefit. We have then a post-colonial state born into governmentality so to speak, so that in addition to stressing notions of citizenship and nation-building, it also becomes understandable how 'delivery' can be seen today as the main legitimising feature of the post-apartheid state in South Africa for example. Not only was this the case, but in adopting technical strategies for modernisation and development, 'older ethnographic concepts often entered the field of knowledge about populations - as convenient descriptive categories for classifying groups of people into suitable targets for administrative, legal, economic or electoral policy' (ibid: 37). Hence, the importance of 'tribes' or religious groups in most of Africa and that of 'races' in South Africa today as objects of policy.

\section{On social movements}

Given the decline and loss of legitimacy of political parties, how then are we to understand the relationship between popular movements and politics, between the social movements of what Hardt and Negri (2001) call 'multitudes', and politics? Hardt and Negri's idealisation of spontaneity imbues the 'multitudes' with the same qualities of a historical subject with which Marx had endowed the proletariat. The 'multitudes' are to be the saviours of humanity, a position largely adhered to also by Samir Amin (Amin and Sridhar 2002). This is quite unconvincing, simply because the politics of many 'multitudes' are still imbued with insurrectionist assumptions for example, a form of politics inherited uncritically from our statist past, as insurrections were meant to take over state power. In any case there can be no historical subject if we are to be consistently anti-humanist. The existence of social movements is not in itself sufficient evidence of an emancipatory alternative, and 
in any case it is in the character of such movements to rise and fall as their concerns become difficult to sustain. What is required in addition to recognising the importance of social movements, is the development, both in theory and in practice, of an emancipatory politics, something which is not simply given by capitalist society.

South Africa is the one African country where the study of social movements is the most developed today. Yet, for the most part, these movements seem to be concerned above all with protesting about the slow pace of state 'delivery' of housing, land, water, electricity, etc., along with the commercialisation of these resources, rather than with providing an alternative vision of society. References to 'socialism' are still left undefined while little attempt so far is made to construct an alternative in practice. The argument of these movements therefore seems to be one which stresses the lack of integration of communities into the capitalist system rather than an alternative to that system. At the same time the economic character of their demands seems to lend these movements a class character to the delight of those wishing to see a 'working class' everywhere (see for example, Alexander 2005). The South Africa literature still seems to either romanticise social movements (Desai and Pithouse 2003), or to maintain that to have so far failed to organise a political party is an indication of the lack of progress of such movements (Ballard et al. 2005). On the other hand, Barchiesi (2005: 237) notes much more accurately that traditional "class-based discourses and practices retain a crucial relevance for community movements that are contesting the neo-liberalisation of the South African transition'. Yet he observes that, given the context of a collapse in wage-employment, 'organizations, emancipatory visions and social claims based on wage-labour are in crisis'. We should add 'sociological theories' to this list. Given this economic situation, and given the growing cynicism with regard to the incumbents of state power, 'classism' has lost much of its explanatory and political relevance. The difficulty has been that there is as yet little to replace it with.

In sum, so far it appears difficult for these movements and their intellectual supporters to think beyond statist or 'classist' political solutions, a perspective more and more at odds with social reality. Clearly, if oppression gives rise to resistance, and we follow Foucault in maintaining that power is a relation which always includes resistance, then the occurrence of resistance is simply part of the oppressive system itself. It should also be recalled that, for Marx, capital was a social relation of exploitation and that this relation was the essence of the capitalist mode of production, with the result that the fact of worker resistance was, for him, inherently part of the capitalist system itself. Labour unions were precisely an expression of such resistance. Current popular movements are not necessarily breaking with capitalism, 
while the latter has shown an uncanny ability to adapt itself to the pressures of 'new social movements' (women's movements, environmentalism etc.), in not altogether different ways through which it had adapted itself to the old. In other words there is nothing inherent in social movements themselves which necessarily bears an emancipatory potential, let alone a project. In fact, when social movements are simply oppositional, simply against what exists, or clamour for state 'delivery', they can easily be demobilised and incorporated. The appropriation of the discourse of popular participation by the World Bank constitutes yet further evidence of this process of the 'infinite flexibility' of capital (Cooke and Kothari 2002). From an emancipatory perspective, the point must be that movements have to propose something new, something additional, some alternative way of life. They must be 'for' something and not simply 'against' what exists. It is only in this way that they can hold the potential for developing an emancipatory mode of politics. I have noted that one historical constant in Africa has been an assertion of an alternative moral order, a conception of a moral community, a community of active citizens. More critical analyses are necessary in order to elicit the existence of such a perspective or something similar to it, among current social movements.

Insofar as political organisation today is concerned, Badiou (2005c) argues that it needs to be fundamentally distinguished from state forms. In particular this means re-thinking political organisation beyond the party form, which fundamentally operates with a state subjectivity. Political parties have the monopoly of political knowledge (the party line); in order to re-think the politics of emancipation in Africa, we need to develop an understanding of political organisations which do not have such a monopoly and in particular the links between political organisation and political movements need to be rethought; these cannot be allowed to reproduce the role of the party or state as the sole fountain of knowledge and power if an emancipatory conception of development is to be developed. In this sense the notion of 'participatory development' which is commonly used as an alternative to the state-driven process is so vague that it covers an array of practices. The various initiatives reviewed in the work of Wignaraja and others on India (where they seem to be furthest developed) do seem to be attempting to develop a logic which is not statist and where community struggles are able to build: 'alternative grassroots processes [which] can serve to reinforce democratic and political processes, and help building structures with social justice built into them' (1990: 103). Yet at the same time, it is clear that such community initiatives are often dependent on a state which is willing to provide a 'political space', an 'enabling environment' for popular mobilisation. Both a truly democratic state which is sensitive to the development of a popularly founded active 
citizenship as well as such an active citizenship itself are apparently needed for an alternative emancipatory conception of development to be possible. Today this environment is being sought in a 'human rights culture' but, as we have seen, this has the opposite effect of reproducing a culture of 'anti-politics'. The potential tyrannical conception of 'community participation' and its takeover by World Bank discourse already noted above, has its roots in the common ideological weakness of popular organisations (Cooke and Kothari 2002).

At this stage, we need to mention the basic condition for an emancipatory politics which as a matter of fact is not always in existence. Zizek (1999: 187-91) has recently discussed this in the work of the post-Althusserian philosophers Balibar, Rancière and Badiou. For Rancière (1995) the political moment is that when those with no place in society, not only demanded that their voice be heard in the 'public sphere' on an equal footing with those in power, but moreover also see themselves as the representatives of the whole of society, for the true universality. Thus Zizek notes, 'political conflict designates the tension between the structured social body in which each part has its place, and "the part of no part" which unsettles this order on account of the empty principle of universality' (ibid.: 188). This is what Balibar (1994: 47) refers to as 'equaliberty', the absolute equality of men as thinking beings, or the 'equation of man and citizen'.

We are now in a better position to distinguish a truly political struggle for rights from an appeal for human rights. A prescriptive demand for rights only becomes emancipatory when, in addition to being fought for by active citizens, it makes a universal appeal. Badiou puts it as follows:

The theme of equal rights is really progressive and really political, that is, emancipatory, only if it finds its arguments in a space open to everyone, a space of universality. If not, despite all the apparent radicalism a community puts into its system of demands, we have a profound submission to the figure of the state [...] (Badiou 1994: 9).

For Badiou politics begins when people (anyone) are militantly faithful to the kinds of events mentioned by Zizek; in his own words: 'politics begins when one decides not to represent victims [...] but to be faithful to those events during which victims politically assert themselves' (Badiou 1985: 75). It goes without saying that such events include popular upsurges throughout the world and particularly, in our context, the popular struggles for national liberation of which one of the most recent was that in South Africa in the mid-1980s (Neocosmos 1998; Van Kessel 2000). Being faithful to such events, means not giving up on the truths of such events, on the new apparently impossible world which such events foretell (Badiou 2001a; Hallward 2004). 
What such events mean is that possibilities now appear as truly possible whereas before they could not be conceived. For example, who would have thought before the Haitian revolution in 1804 that slaves could not only rebel but could defeat both French and British armies to acquire control over their own nation? Who would have thought that Mexican peasants could have created a better world in 1910? Or who would have thought that the people of South Africa would have overthrown the oppressive apartheid state themselves as a result of their own political endeavours? In all these cases and in many others, an egalitarian emancipatory vision was crucial to success. In this way, politics becomes 'the art of the impossible', of making possible what appears as a 'void' from within current knowledge. 'Another world' is indeed possible but it can only be so on the basis of the re-invention of an emancipatory politics appropriate to our conditions.

\section{Concluding remarks}

While the statism of twentieth century development discourses is clear today, not far from the surface also lurked a humanism for which there was nothing which 'Man' was incapable of. A better world could be built by 'Man' through the state. This was a humanism with a project. Today no one denies the importance of the relationship between development and democracy. The problem is that in the overwhelming majority of cases, democracy is reduced to its liberal hegemonic type, or a variant of it. Development as a national emancipatory project has been replaced in Africa and most of the South by human rights discourse, a humanism for which the people of Africa are no longer subjects but only pathetic victims (of authoritarianism, of the market, of natural disasters). Thus, humanism in the twenty-first century has so far been a humanism without a project (statist or otherwise). Citizenship has been reduced to being a client of NGOs. Without a critique of this political liberalism, there can be no emancipatory development, no human emancipation at all. At most, struggles for human rights today seem concerned with incorporation into the existing system, and do not provide a way to transform it. This critique therefore requires both the re-appropriation of a notion of 'active citizenship' as well as the theorisation of a political subject. It is the broad outlines of such a critique which have been attempted here.

While it has been argued that a concept of social citizenship is central today to resolve the contradiction between a coercive state and the existence of a moral community, it was suggested that such social citizenship can only be understood as active citizenship. Moreover, active citizenship cannot on its own provide an emancipatory vision for the future, yet it must provide the conditions of existence of an emancipatory politics, a politics which needs to be thought from scratch in order to distance itself from state politics. The 
development of such a politics is still in its infancy; its sites and possible existence in practice have still to be investigated, while its theorisation only now becomes possible. What is certain is that development and emancipation must be brought back together if we are to remain faithful to the panAfrican emancipatory vision of the African people.

Of all the rights ascribed to humanity, one of the most important, arguably that which distinguishes us from mere biological beings and thus that which makes us truly human, is systematically denied by human rights discourse: this is the right to think. The right to think is denied by denying the possibility of anything different to the consensus of a one way thought (la pensée unique), of anything different to what exists. As a community activist recently stated in South Africa:

The leaders [of the country] are saying that it is them who know everything and that the majority of the people can't think. We are saying that everyone can think (South African activist, cited in Desai and Pithouse 2003:17).

This must be the starting point of a different conception of politics. As stressed by Lazarus (1996) who founds a whole theory of political practice on this axiomatic principle, people are capable of thought, of producing truths. As acclaimed recently by Badiou and his friends (La Distance Politique 2005: 34):

When all is said and done, the issue in contention concerns the freedom to think; [...] in electoral systems there is no freedom of thought. There is only a freedom to hold opinions. This means the freedom to support those in power (in agreement with the government) or those in the opposition (unhappy with the government) and that is all [...] Politics is not an opinion or a consciousness, it is a thought which fixes new possibilities [...] In politics it is better to achieve freedom through thought rather than to be constrained by opinions.

In Africa, the struggle for freedom today is not about joining 'the community of civilised nations' nor is it about 'good governance', these simply restrict thought to that of the consensus of the new empire; rather this struggle is about reclaiming the right to think.

\section{References}

Adesina, J., 2004, 'NEPAD and the Challenge of Africa's Development: Towards the Political Economy of a Discourse', Society in Transition, vol. 35, no. 1. Ake, C., 2003, The Feasibility of Democracy in Africa, Dakar: CODESRIA. Alexander, P., 2005, 'Globalisation and New Social Identities: A Jig-saw Puzzle from Johannesburg', Paper presented at the University of Pretoria, Department of Sociology Seminar, May 10th. 
Althusser, L. 1971, 'Ideology and Ideological State Apparatuses', in Althusser, L. Lenin and Philosophy and Other Essays, London: New Left Books.

Altman, M., 2003, 'The State of Employment and Unemployment in South Africa', in Daniel, J. et al., State of the Nation: South Africa 2003-2004, Cape Town: HSRC Press.

Amadiume, I., 1997, Reinventing Africa, London: Zed Press

Amin, S. and Sridhar, V., 2002, 'For Struggles, Global and National', An interview with Samir Amin by V. Sridhar, Centre for Civil Society, University of KwazuluNatal (www.ukzn.ac.za/ccs/).

Anweiler, O., 1972, Les Soviets en Russie: 1905-1921, Paris: Gallimard.

Arendt, H., 1963, On Revolution, London: Penguin.

Arendt, H., 1982, Lectures on Kant's Political Philosophy, Chicago: University of Chicago Press.

Assiter, A., 1999, 'Citizenship Revisited', in Yuval-Davis, N. and Werbner, P., Women, Citizenship and Difference, London: Zed Press.

Badiou, A., 1982, Théorie du Sujet, Paris: Seuil.

Badiou, A., 1985, Peut-on penser la politique?, Paris: Seuil.

Badiou, A., 1988, L'être et l'évènement, Paris: Seuil.

Badiou, A., 1994, 'Being by Numbers', An interview with Lauren Sedowsky, ArtForum, October.

Badiou, A., 1998a, Abrégé de Métapolitique, Paris: Seuil; English trans. Metapolitics, London: Verso 2005.

Badiou, A., 1998b, D’un désastre obscur: sur la fin de la vérité d'état, Paris: éditions de l'aube.

Badiou, A., 2001a, Ethics: An Essay on the Understanding of Evil, London: Verso. Badiou, A., 2001b, Interview, Cabinet Magazine Online, Issue 5 Winter (http:// www.cabinetmagazine.org/issues/5/alainbadiou.php).

Badiou, A., 2004, 'Beyond Formalisation', Interview with Peter Hallward et Bruno Bosteels, Wednesday 1st December (http://ciepfc.rhapsodyk.net/).

Badiou, A., 2005a, Le Siècle, Paris: Seuil.

Badiou, A., 2005b, 'The Cultural Revolution: The Last Revolution?', Positions, vol. 13, no. 3, Special issue on the Cultural Revolution in China, ed. T. Barlow.

Badiou, A., 2005c, 'AGR interviews Professor Alain Badiou', Ashville Global Report, September (http://mambo.agrnews.rack2.purplecat.net/).

Balibar, E., 1994, "Rights of Man" and "Rights of the Citizen": The Modern Dialectic of Equality and Freedom', in E. Balibar, Masses, Classes, Ideas: Studies on Politics and Philosophy before and after Marx, New York and London: Routledge.

Ballard, R. et al., 2005, 'An Anatomy of New Power', Mail \& Guardian, 21st January.

Barchiesi, F., 2005, 'Classes, Multitudes and the Politics of Community Movements in Post-apartheid South Africa', in Gibson, N., ed., Challenging Hegemony: Social Movements and the Quest for a New Humanism in South Africa, New Jersey: Africa World Press.

Césaire, A., 1972, Discourse on Colonialism, New York: Monthly Review Press. 
Chatterjee, P., 1993, The Nation and Its Fragments: Colonial and Postcolonial Histories, Princeton: Princeton University Press.

Chatterjee, P., 2004, The Politics of the Governed: Reflections on Popular Politics in Most of the World, New York: Columbia University Press.

Chatterjee, P. and Pandey, G., eds., 1992, Subaltern Studies VII, Delhi: Oxford University Press.

Constitutional Assembly (of the Republic of South Africa), 1997, The Constitution of the Republic of South Africa, Annotated Version, Constitutional Assembly.

Cooke, B. and Kothari, U., eds., 2002, Participation: the New Tyranny, New York and London: Zed Books.

Cowen, M.P. and Shenton, R.W., 1996, Doctrines of Development, London: Routledge.

Cowen, M.P. and Laakso, L., eds., 2002, Multi-party Elections in Africa, Oxford: James Currey.

Desai, A. and Pithouse, R., 2003, “But We Were Thousands": Dispossession, Resistance, Repossession and Repression in Mandela Park', CCS Research Report No. 9.

Englund, H., 2004, 'Transnational Governance and the Pacification of Youth: The Contribution of Civic Education to Disempowerment in Malawi', CCS Research Report No. 13, Durban.

Erwin, A., 1998, 'Government is not an NGO', South African Labour Bulletin, vol. 22, no. 3, June.

Fanon, F., 1989, Studies in a Dying Colonialism, London: Earthscan.

Fanon, F., 1990, The Wretched of the Earth, London: Penguin.

Finley, M. I., 1985, Democracy Ancient and Modern, London: The Hogarth Press.

Foucault, M., 2000, Power: Essential Works of Foucault 1954-1984 vol 3, London: Penguin.

Frederich Ebert Stiftung, 2004, 'What Kind of Future? Modernization and Organisational Reform of Political Parties', and Statement by Ulrich Golaszinski, Maputo, 20-22 October.

Fullard, M. and Rousseau, N., 2003, 'An Imperfect Past: Truth and Reconciliation Commission in Transition', in Daniel, J., Habib, A., and Southall, R., eds., State of the Nation: South Africa 2003-2004, Cape Town: HSRC Press.

Gramsci, A., 1971, Selections from the Prison Notebooks, London: Lawrence and Wishart.

Hallward, P., 2003, Badiou: A Subject to Truth, Minneapolis and London: University of Minnesota Press.

Hardt, M. and Negri, A., 2001, Empire, Cambridge: Harvard University Press.

Hassim, S., 1999, 'From Presence to Power: Women's Citizenship in a New Democracy', Agenda, no. 40.

Harvey, D., 1990, The Condition of Postmodernity, Cambridge, Mass: Blackwell. Harvey, D., 2005, The New Imperialism, Oxford: Oxford University Press.

Kanyinga, K. and Katumanga, M., 2003, 'Citizenship and Rights: The Failures of the Post-colonial State in Africa', Africa Development, vol. 28, nos. 1\&2. 
Krenshaw, K., 2000, 'Were the Critics Right about Rights? Reassessing the American Debate about Rights in the Post-reform Era', in M. Mamdani, ed., Beyond Rights Talk and Culture Talk, Cape Town: David Philip.

La Distance Politique, 2005, 'Parler Politique, Parler de la Politique', Supplément à La Distance Politique, Mars.

Lazarus, S., 1996, Anthropologie du Nom, Paris: Seuil.

Lenin, V.I., 1918, 'The Immediate Tasks of the Soviet Government', in Collected Works, volume 27, London: Lawrence and Wishart.

Lenin, V.I., 1919, 'The Trade Unions, the Present Situation and Trotsky's Mistakes', in Collected Works volume 32, London: Lawrence and Wishart.

Mamdani, M., 1987, 'Contradictory Class Perspectives on the Question of Democracy: The case of Uganda', in Anyang Nyong'o, P., ed., Popular Struggles for Democracy in Africa, London: Zed Books.

Mamdani, M., 1995, 'Democratic Theory and Democratic Struggles', in Chole, E. and Ibrahim, J., eds., Democratisation Processes in Africa: Problems and Prospects, Dakar: CODESRIA.

Marshall, T.H., 1964, Class, Citizenship and Social Development, Chicago: University of Chicago Press.

Marx, K., 1844, 'Toward a Critique of Hegel's Philosophy of Right. Introduction', in D. McLellan, ed., Karl Marx: Early Texts, Oxford: Blackwell 1971.

Meister, R., 2002, 'Human Rights and the Politics of Victimhood', Ethics and International Affairs, vol. 16, no. 2.

Mutua, M.W., 2002, Human Rights: A Political and Cultural Critique, Philadelphia: University of Pennsylvania.

Neocosmos, M., 1998, 'From People's Politics to State Politics: Aspects of National Liberation in South Africa', in A. Olukoshi, ed., The Politics of Opposition in Contemporary Africa, Uppsala: Nordic Africa Institute.

Neocosmos, M., 1999, 'Intellectual Debates and Popular Struggles in Transitional South Africa: Political Discourse and the Origins of Statism', Seminar, Centre for African Studies, University of Cape Town, April 21.

Neocosmos, M., 2003, "The Contradictory Position of "Tradition" in African Nationalist Discourse: Some Analytical Reflections', Africa Development, Special Issue on 'Globalization and Citizenship in Africa', vol. 28, nos. $1 \& 2$.

Neocosmos, M., 2005, 'Rethinking Politics in Southern Africa Today: Elements of a Critique of Political Liberalism', in Gibson, N., ed., Challenging Hegemony, New Jersey: Africa World Press.

Neocosmos, M., 2006, From Foreign Natives to Native Foreigners: Explaining Xenophobia in Post-apartheid South Africa, Dakar: CODESRIA Books.

Poulantzas, N., 1978, State, Power, Socialism, London: New Left Books.

Rancière, J., 1995, La Mésentente, Paris: Galilée.

Rawls, J., 2003, The Law of Peoples, Cambridge, Mass. Harvard University Press. Rueschemeyer, D., Stephens, E.H. and Stephens, J.D., 1992, Capitalist Development and Democracy, London: Polity Press.

Scott, J., 1998, Seeing Like a State: How Certain Schemes to Improve the Human Condition Have Failed, New Haven: Yale University Press. 
Sen, A.K., 1999, Development as Freedom, Oxford: Oxford University Press.

Shivji, I., ed., 1985, The State and the Working People in Tanzania, Dakar: CODESRIA.

Shivji, I., ed., 1991, State and Constitutionalism: An African Debate on Democracy, Harare: SAPES Books.

Sibanda, A., 2002, 'Voicing a Peasant Alternative: The Organisation of Rural Associations of Progress (ORAP) in Zimbabwe', in Ben Romdhane, M. and Moyo, S., eds., Peasant Organisations and the Democratisation Process in Africa, Dakar: CODESRIA.

Stedman-Jones, G., 2004, An End to Poverty?, London: Profile Books.

Taylor, H., 2002, 'Insights into Participation from Critical Management and Labour Process Perspectives', in Cooke, B. and Kothari, U., Participation: the New Tyranny, London: Zed Books.

Van Kessel, I., 2000, "Beyond our Wildest Dreams": The United Democratic Front and the transformation of South Africa, Charlottesville and London: University of Virginia Press.

Wamba-dia-Wamba, E., 1994, 'Africa in Search of a New Mode of Politics', in H. Himmelstrand, ed., African Perspectives on Development, London: James Currey.

Wamba-dia-Wamba, E., 1985, 'Experience of Democracy in Africa: Reflections on the Practice of Communalist Palaver as a Method of Resolving Contradictions Among the People', Philosophy and Social Action, JulySeptember, vol. 11, no. 3.

Wilson, R. A., 2001, The Politics of Truth and Reconciliation in South Africa: Legitimizing the Post-apartheid State, Cambridge: Cambridge University Press.

Zizek, S., 1999, The Ticklish Subject: the Absent Centre of Political Ontology, London: Verso. 